\section{BRAZIULIAN JOURNAL \\ OF MIEDICAL AND BIOLOGICAL RESFARCH}

www.bjournal.com.br
ISSN 0100-879X

Volume 42 (12) 1119-1247 December 2009

BIOMEDICAL SCIENCES

AND

CLINICAL INVESTIGATION

Braz J Med Biol Res, December 2009, Volume 42(12) 1138-1142

Effect of estrogen receptor-alpha (ESR1) gene polymorphism on high-density lipoprotein levels in response to hormone replacement therapy

N.C. Nogueira-de-Souza, I.D.C. Guerreiro da Silva, C.V. de Carvalho, A. Pulchinelli, M.A. Haidar, E.C. Baracat and A.M. Massad-Costa

The Brazilian Journal of Medical and Biological Research is partially financed by
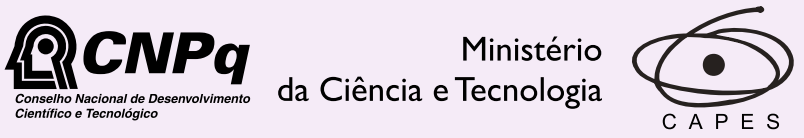

Ministério da Educação

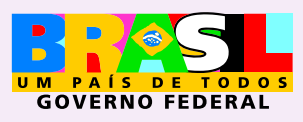

Institutional Sponsors

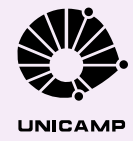




\title{
Effect of estrogen receptor-alpha (ESR1) gene polymorphism on high-density lipoprotein levels in response to hormone replacement therapy
}

\author{
N.C. Nogueira-de-Souza1 ${ }^{1}$ I.D.C. Guerreiro da Silva ${ }^{1}$, C.V. de Carvalho', \\ A. Pulchinelli ${ }^{1}$, M.A. Haidar ${ }^{1}$, E.C. Baracat ${ }^{2}$ and A.M. Massad-Costa ${ }^{1}$ \\ ${ }^{1}$ Laboratório de Biologia Molecular, Departamento de Ginecologia, Escola Paulista de Medicina, \\ Universidade Federal de São Paulo, São Paulo, SP, Brasil \\ ${ }^{2}$ Departamento de Obstetrícia e Ginecologia, Faculdade de Medicina, \\ Universidade de São Paulo, São Paulo, SP, Brasil
}

\begin{abstract}
Studies have shown that estrogen replacement therapy and estrogen plus progestin replacement therapy alter serum levels of total, LDL and HDL cholesterol levels. However, HDL cholesterol levels in women vary considerably in response to hormone replacement therapy (HRT). A significant portion of the variability of these levels has been attributed to genetic factors. Therefore, we investigated the influence of estrogen receptor-alpha (ESR1) gene polymorphisms on HDL levels in response to postmenopausal HRT. We performed a prospective cohort study on 54 postmenopausal women who had not used HRT before the study and had no significant general medical illness. HRT consisted of conjugated equine estrogen and medroxyprogesterone acetate continuously for 1 year. The lipoprotein levels were measured from blood samples taken before the start of therapy and after 1 year of HRT. ESR1 polymorphism (Mspl C>T, Haelll C>T, Pvull C>T, and Xbal A>G) frequencies were assayed by restriction fragment length polymorphism. A general linear model was used to describe the relationships between HDL levels and genotypes after adjusting for age. A significant increase in HDL levels was observed after HRT $(P=0.029)$. Women with the ESR1 Pvull TT genotype showed a statistically significant increase in HDL levels after HRT $(P=0.032)$. No association was found between other ESR1 polymorphisms and HDL levels. According to our results, the ESR1 Pvull TT genotype was associated with increased levels of HDL after 1 year of HRT.
\end{abstract}

Key words: Hormone replacement therapy; High-density lipoprotein cholesterol levels; Estrogen receptor-alpha; Polymorphism

\section{Introduction}

Estrogen exerts beneficial systemic effects on lipoprotein and antioxidant metabolism through estrogen receptoralpha (ESR1) (1). It is clear that estrogen levels decline in women during menopause and that this is one reason for the increase in plasma low-density lipoprotein (LDL) levels. LDL is one of the lipoproteins that promote endothelial damage, as well as reduction of high-density lipoprotein (HDL), a pleiotropic lipoprotein that prevents or alleviates endothelial damage (2). Studies have shown that estrogen replacement therapy and estrogen plus progestin replacement therapy alter these levels by decreasing LDL cholesterol levels and increasing HDL cholesterol levels $(3,4)$. However, HDL cholesterol levels in women vary considerably in response to hormone replacement therapy (HRT) and a significant portion of the variability in HDL cholesterol levels can be attributed to genetic factors (5-7).

ESR1 is a member of a nuclear hormone receptor superfamily and acts as a ligand-activated transcription factor composed of several domains that are important for hormone and DNA binding (8). The human ESR1 gene is located on the long arm of chromosome 6 (6q25.1) and contains 8 exons separated by 7 intronic regions $(9,10)$. Several single nucleotide polymorphisms (SNP) of the ESR1 gene have been identified, of which the Mspl C>T (National Center for Biotechnology Information SNP identification, NCBI SNP ID: rs1784705) SNP in the first exon and Haell

Correspondence: I.D.C. Guerreiro da Silva, Rua Pedro de Toledo, 781, 04039-032 São Paulo, SP, Brasil. Fax: +55-11-5579-8715.

E-mail: ismael.toco@epm.br

Received May 12, 2009. Accepted November 4, 2009. Available online November 23, 2009. Published December 4, 2009. 
C>T (NCBI SNP ID: rs9322331), Pvull C>T (NCBI SNP ID: rs2234693) and $X b a l A>G$ (NCBI SNP ID: rs9340799). SNP in the first intron have been studied the most. For example, polymorphic alterations of the ESR1 gene have been evaluated in studies of possible linkage and/or association with endometrial cancer (11), breast cancer (12), ovarian cancer (13), prostate cancer (14), leiomyoma $(15,16)$, endometriosis (16-18), bone mineral density $(19,20)$, and cardiovascular disease (21) with discrepant results in studies that included a very different number of patients. However, very few of them were designed to compare the same patient before and after HRT.

Data concerning an association of ESR1 genetic polymorphisms with lipid profiles in postmenopausal women have been contradictory. Some studies of postmenopausal women did not detect an association between ESR1 polymorphisms and serum lipoprotein levels after HRT (22-25). However, Herrington et al. (26) reported that postmenopausal women who were ESR1 Pvull CC carriers, as well as those with several other closely linked intron 1 polymorphisms, had an increase in HDL cholesterol levels after HRT. Later, these results were supported by the observation that postmenopausal women with an ESR 1 Pvull CC genotype had an increase response of HDL, apolipoprotein A1, vascular reactivity, and myocardial perfusion to HRT (27). On the other hand, Huang et al. (28) have reported that healthy postmenopausal women with the CC or TC genotype in ESR1 Pvull restriction had higher serum total cholesterol and LDL cholesterol concentrations.

The objective of the present study was to determine if there is an association between Mspl C>T, HaellI C>T, Pvull $\mathrm{C}>\mathrm{T}$, and Xbal A>G ESR1 SNP and plasma HDL cholesterol levels in postmenopausal women who were treated with conjugated equine estrogen and medroxyprogesterone acetate continuously for 1 year.

\section{Material and Methods}

One hundred non-hysterectomized and postmenopausal women were enrolled in the study, which was approved by the Ethics Committee of the Federal University of São Paulo (Brazil). All patients gave written informed consent to participate. No patient had been previously treated with HRT and all had a maximum of 3 years of menopause. Other exclusion criteria were a history of breast or endometrial cancer, deep vein thrombosis, uncontrolled hypertension, valvular or congenital heart disease, heart failure, cardiomyopathy, diabetes, and renal or thyroid disease. Fifty-four women were initially included, after 46 had been excluded due to thyroid, kidney, liver, and/or diabetes problems.

HRT consisted of $0.625 \mathrm{mg} /$ day conjugated equine estrogen and $2.5 \mathrm{mg} /$ day medroxyprogesterone acetate continuously for 1 year, with a medical visit every 3 months. Blood samples were obtained between 8 and 9 am after overnight fasting before and after 1 year of treatment for the determination of HDL levels on day zero (HDLpre) and after 1 year of treatment (HDLpost). All samples were analyzed immediately after collection. Routine chemical methods were used to determine lipoprotein levels (Bayer Healthcare, USA).

Genomic DNA was extracted from peripheral blood leukocytes using the Easy-DNA ${ }^{\mathrm{TM}}$ Kit (Invitrogen Corporation, USA) according to manufacturer instructions. The DNA $(0.2 \mu \mathrm{g})$ was amplified in $50 \mu \mathrm{L}$ PCR Master Mix (Promega Corporation, USA). Five micromoles per microliter of oligonucleotide primer set was used for each reaction. The polymerase chain reaction (PCR) was performed for 35 cycles to amplify each specific fragment of the ESR1 gene. The PCR conditions, oligonucleotide primers, and genotype sizing were described elsewhere $(26,29,30)$.

After PCR amplification, the polymorphisms were assayed using restriction fragment length polymorphism (RFLP). Each PCR product was incubated with 3 units of a specific restriction enzyme at $37^{\circ} \mathrm{C}$ for $4 \mathrm{~h}$ and the resulting fragments were visualized on a $3 \%$ ethidium bromidestained agarose gel using UV light and documented with a digital camera (Eastman Kodak Co., USA). Genotypes for Mspl, HaellI, and Pvull polymorphisms were termed CC/ $\mathrm{CT} / \mathrm{TT}$, and $\mathrm{Xbal}$ polymorphisms were AA/AG/GG and CC/ $\mathrm{CT} / \mathrm{TT}$, respectively.

The chi-square test was used to test for significant departures from Hardy-Weinberg equilibrium. Pairwise linkage disequilibrium (D') was calculated using the linkage disequilibrium pairs program from the GENECOUNTING utilities (31) and the WHAP software (http://pngu.mgh. harvard.edu/ purcell/whap/) was used to estimate haplotype frequencies. HDL levels were calculated during the trial as mean follow-up measurements obtained before (HDLpre) and after (HDLpost) treatment. A general linear model was used to describe the relationships between HDL levels and various genotypes after adjusting for age. A paired sample $t$-test and one-way ANOVA were employed for within- and between-group comparisons, respectively.

\section{Results}

Fifty-four women started the treatment. Mean age $( \pm$ SD) was $51.7 \pm 3.6$ years. Plasma HDL levels were 55.33 $\pm 14.49 \mathrm{mg} / \mathrm{dL}$ before and $58.24 \pm 14.36 \mathrm{mg} / \mathrm{dL}$ after HRT. A significant difference in HDL levels was observed before and after HRT $(P=0.029)$. After HRT, HDL levels were maintained or decreased in $35.2 \%(N=19)$ of these postmenopausal patients, but were increased in the remaining $64.8 \%(\mathrm{~N}=35)$.

The genotype frequencies of the estrogen receptoralpha gene polymorphisms ESR1 Mspl C>T, ESR1 Haell $\mathrm{C}>\mathrm{T}$, ESR1 Pvull $\mathrm{C}>\mathrm{T}$, and ESR1 $X$ bal $\mathrm{A}>\mathrm{G}$ are shown in Table 1. The four ESR1 SNP were in Hardy-Weinberg equilibrium $(P>0.05)$. The three ESR1 SNP in intron 1 
were in linkage disequilibrium with each other (Haelll $\mathrm{C}>\mathrm{T}$ with Pvull T>C; HaellI $\mathrm{C}>\mathrm{T}$ with $\mathrm{Xbal} \mathrm{A}>\mathrm{G}$ and $\mathrm{Xbal}$ A $>$ G with Pvull C>T; D' = 1.000; $P<0.0001$ ). No linkage disequilibrium was observed between the SNP in exon 1 and the SNP in intron 1.

We analyzed the genotype of the ESR1 gene together with plasma HDL levels before and after HRT (Table 1). After 1 year of HRT, we observed an increase in plasma HDL levels in all ESR1 genotypes. There was no significant difference in HDLpre or HDLpost levels in ESR1 Mspl genotypes (Mspl CC: $\mathrm{P}=0.786 ;$ Mspl CT: $\mathrm{P}=0.069 ;$ Mspl TT: $\mathrm{P}=0.191$ ), ESR1 Haell genotypes (Haelll CC: $\mathrm{P}=0.074$; Haell CT: $P=0.518$; Haell TT: $P=0.241)$, or ESR1 Xbal genotypes (Xbal AA: $P=0.142 ; X b a l$ AG: $P=0.417$; $X b a l$ GG: P = 0.101). However, in ESR1 Pvull genotypes, Pvull TT carriers showed a statistically significant increase in HDL levels after HRT ( $P=0.032)$. In the other Pvull genotypes, the increase of HDL levels was not significantly different after HRT (Pvull CC: $\mathrm{P}=0.246$; Pvull CT: $\mathrm{P}=0.592$ ).

Analyses using the mean difference in HDL levels as a quantitative trait did not provide evidence of an association for the following haplotypes: i) alleles of the four markers (likelihood ratio test, LRT $=0.370 ; P=0.831$ ); ii), the strongly linked combination of ESR1 Haell, ESR1 Pvull and ESR1 Xbal (LRT = 3.11; P = 0.370); iii) the ESR Mspl/ESR1 Haell combination (LRT $=0.563 ; P=0.755)$; iv), the ESR1 Haell/ ESR1 Pvull combination (LRT = 1.22; $\mathrm{P}=0.544)$, and $\mathrm{v}$ ) the ESR1 Pvull and ESR1 Xbal combination (LRT = 3.10; $P=0.210)$.

\section{Discussion}

Endogenous and exogenous estrogens have been reported to affect the hemostatic system and to exert effects on lipoprotein metabolism $(2,3)$. In the present study, we determined whether estrogen receptor-alpha (ESR1 Mspl C>T, Haell C $>$ T, Pvull C>T, and Xbal A>G) gene polymorphisms are associated with high HDL levels in women undergoing postmenopausal hormone replacement therapy. ESR1 Pvull TT carriers showed a statistically significant increase in HDL levels after HRT (HDLpre = 53.25 \pm 15.70; HDLpost $=57.60$ \pm 14.35 ; $P=0.032$ ). No association was found between the three other polymorphisms and HDL levels.

The previous in vitro observations of allele-dependent differences of ESR1 Pvull polymorphisms and HDL levels are contradictory. Herrington et al. (6) showed that the ESR1 Pvull T allele eliminates a functional binding site for the transcription factor $M y b$, which suggests that the presence of this allele may result in lower ESR1 transcription, and postmenopausal Pvull CC carriers showed increased HDL cholesterol levels in response to HRT (26). However, Figtree et al. (32) showed that the variant T allele of ESR1 $P$ vull abolished the negative transcriptional regulation by an adjacent glucocorticoid receptor binding sequence, and was strongly associated with HDL levels in a large cohort
Table 1. Genotype frequencies and high-density lipoprotein levels before (HDLpre) and after (HDLpost) hormone replacement therapy in each estrogen receptor-alpha polymorphism.

\begin{tabular}{lccc}
\hline Genotype & Frequency (\%) & HDLpre & HDLpost \\
\hline Mspl CC & $7(13)$ & $57.29 \pm 9.99$ & $58.57 \pm 13.08$ \\
Mspl CT & $25(46)$ & $52.44 \pm 14.24$ & $55.96 \pm 15.78$ \\
Mspl TT & $22(41)$ & $58.00 \pm 15.84$ & $60.73 \pm 13.19$ \\
& & & \\
HaellI CC & $38(70)$ & $55.58 \pm 15.06$ & $58.16 \pm 13.46$ \\
Haelll CT & $12(22)$ & $53.92 \pm 12.66$ & $56.25 \pm 15.33$ \\
Haell TT & $4(8)$ & $57.25 \pm 17.67$ & $65.00 \pm 21.67$ \\
& & & \\
Pvull CC & $11(20)$ & $57.64 \pm 18.08$ & $61.64 \pm 17.40$ \\
Pvull CT & $23(43)$ & $56.04 \pm 11.72$ & $57.17 \pm 13.19$ \\
Pvull TT & $20(37)$ & $53.25 \pm 15.70$ & $57.60 \pm 14.35^{\star}$ \\
& & & \\
Xbal AA & $28(52)$ & $56.36 \pm 14.49$ & $58.93 \pm 14.34$ \\
Xbal AG & $21(39)$ & $54.14 \pm 12.05$ & $55.95 \pm 13.51$ \\
Xbal GG & $5(9)$ & $54.60 \pm 16.41$ & $64.00 \pm 18.90$ \\
\hline
\end{tabular}

Data are reported as means $\pm \mathrm{SD}$ in $\mathrm{mg} / \mathrm{dL}$. ${ }^{*} \mathrm{P}<0.05$, HDLpost compared to HDLpre (t-test).

of postmenopausal women. Moreover, they suggested that the functional promoter variant associated with increased HDL might act by increasing ESR 1 expression and that the ESR1 Pvull polymorphism may also alter both beneficial and detrimental responses to exogenous estrogen administered in the form of HRT.

Importantly, we observed a significant increase of HDL levels in this postmenopausal group after HRT. In this regard, it would be interesting to suggest that for patients with low HDL levels the genotyping procedure could define more accurately the type of patient who would benefit from HRT. Moreover, only Pvull TT carriers, but not Pvull CC carriers, had a significant increase in HDL levels after 1 year of hormone replacement. The limitation of our study is the relatively small number of patients included. However, a strength of our study is that it is a prospective study of the Brazilian population, comparing the same women before and after HRT to address the question of whether or not HDL levels are associated with the ESR1 genotype.

We showed here that in our sample of Brazilian postmenopausal women with the ESR1 Pvull TT genotype, there is a significantly higher serum HDL lipoprotein concentration after HRT than in women with the Pvull CC or CT genotype.

\section{Acknowledgments}

Research supported by FAPESP (\#03/04533-1 and \#04/05281-9) and CNPq. 


\section{References}

1. Knopp RH, Zhu X. Multiple beneficial effects of estrogen on lipoprotein metabolism. J Clin Endocrinol Metab 1997; 82: 3952-3954.

2. Li Z, McNamara JR, Fruchart JC, Luc G, Bard JM, Ordovas $\mathrm{JM}$, et al. Effects of gender and menopausal status on plasma lipoprotein subspecies and particle sizes. J Lipid Res 1996; 37: 1886-1896.

3. Lamon-Fava S, Posfai B, Asztalos BF, Horvath KV, Dallal GE, Schaefer EJ. Effects of estrogen and medroxyprogesterone acetate on subpopulations of triglyceride-rich lipoproteins and high-density lipoproteins. Metabolism 2003; 52: 1330-1336.

4. Chang TC, Lien YR, Chen M, Cheng SP, Chen RJ, Chow SN. Effect of conjugated equine estrogen in combination with two different progestogens on the risk factors of coronary heart disease in postmenopausal Chinese women in Taiwan: a randomized one-year study. Acta Obstet Gynecol Scand 2004; 83: 661-666.

5. Cubrilo-Turek M, Sertic J, Durakovic Z. Angiotensin-converting enzyme gene polymorphism, lipids, and apolipoproteins in menopausal women on hormone replacement therapy. Acta Med Croatica 2001; 55: 161-167.

6. Herrington DM, Howard TD, Brosnihan KB, McDonnell DP, Li $X$, Hawkins GA, et al. Common estrogen receptor polymorphism augments effects of hormone replacement therapy on E-selectin but not C-reactive protein. Circulation 2002; 105: 1879-1882.

7. Manresa JM, Zamora A, Tomas M, Senti M, Fito M, Covas $\mathrm{MI}$, et al. Relationship of classical and non-classical risk factors with genetic variants relevant to coronary heart disease. Eur J Cardiovasc Prev Rehabil 2006; 13: 738-744.

8. Parker MG, Arbuckle N, Dauvois S, Danielian P, White R. Structure and function of the estrogen receptor. Ann $N$ Y Acad Sci 1993; 684: 119-126.

9. Menasce LP, White GR, Harrison CJ, Boyle JM. Localization of the estrogen receptor locus (ESR) to chromosome $6 q 25.1$ by FISH and a simple post-FISH banding technique. Genomics 1993; 17: 263-265.

10. Pelletier G, El-Alfy M. Immunocytochemical localization of estrogen receptors alpha and beta in the human reproductive organs. J Clin Endocrinol Metab 2000; 85: 4835-4840.

11. Weiderpass E, Persson I, Melhus H, Wedren S, Kindmark A, Baron JA. Estrogen receptor alpha gene polymorphisms and endometrial cancer risk. Carcinogenesis 2000; 21: 623627.

12. Shen $Y$, Li DK, Wu J, Zhang Z, Gao E. Joint effects of the CYP1A1 Mspl, ERalpha Pvull, and ERalpha Xbal polymorphisms on the risk of breast cancer: results from a population-based case-control study in Shanghai, China. Cancer Epidemiol Biomarkers Prev 2006; 15: 342-347.

13. Wu HJ, Sekine M, Kashima K, Hirai Y, Hatae M, Kobayashi I, et al. Mutational analysis of the estrogen receptor-alpha gene in familial ovarian cancer. J Obstet Gynaecol Res 2005; 31: 375-383.

14. Hernandez J, Balic I, Johnson-Pais TL, Higgins BA, Torkko $\mathrm{KC}$, Thompson IM, et al. Association between an estrogen receptor alpha gene polymorphism and the risk of prostate cancer in black men. J Urol 2006; 175: 523-527.

15. Villanova FE, Andrade PM, Otsuka AY, Gomes MT, Leal ES,
Castro RA, et al. Estrogen receptor alpha polymorphism and susceptibility to uterine leiomyoma. Steroids 2006; 71: 960965.

16. Hsieh YY, Wang YK, Chang CC, Lin CS. Estrogen receptor alpha-351 $\mathrm{Xbal}^{*} \mathrm{G}$ and $-397 \mathrm{Pvull}^{*} \mathrm{C}$-related genotypes and alleles are associated with higher susceptibilities of endometriosis and leiomyoma. Mol Hum Reprod 2007; 13: 117-122.

17. Luisi S, Galleri L, Marini F, Ambrosini G, Brandi ML, Petraglia F. Estrogen receptor gene polymorphisms are associated with recurrence of endometriosis. Fertil Steril 2006; 85: 764766.

18. Sato H, Nogueira-de-Souza NC, D'Amora P, Silva ID, Girao MJ, Schor E. Intron 1 and exon 1 alpha estrogen receptor gene polymorphisms in women with endometriosis. Fertil Steril 2008; 90: 2086-2090.

19. Greendale GA, Chu J, Ferrell R, Randolph JF Jr, Johnston JM, Sowers MR. The association of bone mineral density with estrogen receptor gene polymorphisms. Am J Med 2006; 119: S79-S86.

20. Wang CL, Tang XY, Chen WQ, Su YX, Zhang CX, Chen YM. Association of estrogen receptor alpha gene polymorphisms with bone mineral density in Chinese women: a metaanalysis. Osteoporos Int 2007; 18: 295-305.

21. Shearman AM, Cupples LA, Demissie S, Peter I, Schmid $\mathrm{CH}$, Karas $\mathrm{RH}$, et al. Association between estrogen receptor alpha gene variation and cardiovascular disease. JAMA 2003; 290: 2263-2270.

22. Matsubara Y, Murata M, Kawano K, Zama T, Aoki N, Yoshino $\mathrm{H}$, et al. Genotype distribution of estrogen receptor polymorphisms in men and postmenopausal women from healthy and coronary populations and its relation to serum lipid levels. Arterioscler Thromb Vasc Biol 1997; 17: 3006-3012.

23. Bagger $Y Z$, Hassager $C$, Heegaard AM, Christiansen C. Vitamin $D$ receptor and estrogen receptor gene polymorphisms in postmenopausal Danish women: no relation to bone markers or serum lipoproteins. Climacteric 2000; 3 : 84-91.

24. Almeida S, Fiegenbaum M, de Andrade FM, Osorio-Wender MC, Hutz MH. ESR1 and APOE gene polymorphisms, serum lipids, and hormonal replacement therapy. Maturitas 2006; 54: 119-126.

25. Silvestri S, Thomsen AB, Gozzini A, Bagger Y, Christiansen $C$, Brandi ML. Estrogen receptor alpha and beta polymorphisms: is there an association with bone mineral density, plasma lipids, and response to postmenopausal hormone therapy? Menopause 2006; 13: 451-461.

26. Herrington DM, Howard TD, Hawkins GA, Reboussin DM, Xu J, Zheng SL, et al. Estrogen-receptor polymorphisms and effects of estrogen replacement on high-density lipoprotein cholesterol in women with coronary disease. $N$ Engl J Med 2002; 346: 967-974.

27. Emre A, Sahin S, Erzik C, Nurkalem Z, Oz D, Cirakoglu B, et al. Effect of hormone replacement therapy on plasma lipoproteins and apolipoproteins, endothelial function and myocardial perfusion in postmenopausal women with estrogen receptor-alpha IVS1-397 C/C genotype and established coronary artery disease. Cardiology 2006; 106: 44-50.

28. Huang Q, Wang TH, Lu WS, Mu PW, Yang YF, Liang WW, et 
al. Estrogen receptor alpha gene polymorphism associated with type 2 diabetes mellitus and the serum lipid concentration in Chinese women in Guangzhou. Chin Med J 2006; 119: 1794-1801.

29. Kobayashi S, Inoue S, Hosoi T, Ouchi Y, Shiraki M, Orimo $\mathrm{H}$. Association of bone mineral density with polymorphism of the estrogen receptor gene. J Bone Miner Res 1996; 11: 306-311.

30. Yaich L, Dupont WD, Cavener DR, Parl FF. Analysis of the $P$ vull restriction fragment-length polymorphism and exon structure of the estrogen receptor gene in breast cancer and peripheral blood. Cancer Res 1992; 52: 77-83.

31. Zhao JH. 2LD, GENECOUNTING and HAP: Computer programs for linkage disequilibrium analysis. Bioinformatics 2004; 20: 1325-1326.

32. Figtree GA, Grieve SM, Speller B, Geiger MJ, Robinson BG, Channon $\mathrm{KM}$, et al. A commonly occurring polymorphism upstream of the estrogen receptor alpha alters transcription and is associated with increased HDL. Atherosclerosis 2008; 199: 354-361. 